\title{
Alternative Crop Development Efforts in Minnesota
}

\author{
Luther Waters, Jr. ${ }^{1}$ \\ University of Minnesota, St. Paul, MN 55108
}

At the University of Minnesota, as at most other land grant universities, a significant part of extension and applied research serves development of the agricultural industry. This effort includes expansion of existing industries as well as initiation and development of new business. This work involves a wide range of activities, from feasibility studies to market development and other traditional activities, e.g., research, education, demonstration, etc. It was this concept of mission/responsibility that led to the development of the Asparagus, Broccoli and Cauliflower Industry Development Project (ABC Project) and the Center for Alternative Plant and Animal Products in Minnesota.

A systems approach was used in developing the ABC Project that concentrated on development of a complete support system for new industries. This support system consisted of efforts in feasibility, research, grower education, market development, and product handling systems.

Funding for project implementation is a major problem in any development effort and the ABC Project was no exception. The funding for this project was generated by first obtaining internal support for the idea, then getting the endorsement of key individuals in the agricultural community, and, finally, finding a source of financial support. Support for the ABC Project $(\$ 177,600)$ came from a state agency, the Governor's Council on Rural Development, and was presented as a 3-year effort. Other sources of funds available for this type of project might include benevolent foundations, industry groups, interested (or benevolent) individuals, federal agencies, and others.

The ABC Project was completed in 1984 and the work that was done is outlined below:

A) Feasibility. Development of the project was preceded by a preliminary study of the market for asparagus, broccoli, and cauliflower grown in Minnesota for processing and/or fresh market.

'Professor and Extension Horticulturist-Vegetables, Dept. of Horticultural Sciences, and Director, Center for Alternative Plant and Animal Products. Current address: Dept. of Horticulture, Ohio State Univ., 2001 Fyffe Court, Columbus, OH 43210-1096.
After project funding was obtained, further study was required to identify the strength and location of other markets.

B) Research. Research (Adler et al., 1984, 1985; Dufault and Waters, 1984, 1985a, 1985b) was and is being conducted to demonstrate production potential and appropriate cultural practices, solve problems that limit production and quality, and build grower confidence. Completion of the 3-year project did not negate the need for research. The results encouraged interest by other funding sources.

C) Grower education. Annual production conferences up to 2 days long were conducted during the project to present crop production, management, postharvest handling, and marketing information. Grower tours (Waters and Sherman, 1986) were conducted annually to other parts of the United States where asparagus, broccoli, and cauliflower are being grown. Those working on the project assisted growers in establishing plantings of all three crops. Production publications were prepared (Dufault et al., 1983; Waters et. al., 1983) and distributed to interested growers.

D) Market development. Market development concentrated on two essential areas: a) identifying interested growers who had the resources and entrepreneurial skills to be successful, and b) helping those growers identify appropriate markets for their products and facilitate constructive interaction of growers and product buyers. Of the 50 to 60 growers contacted, only 10 were involved in initial plantings. These efforts are continuous, as are efforts to identify new markets. This is an essential activity since marketing is the first problem a grower must solve.

E) Product handling systems. Acceptability of a product in the marketplace is limited by the way products are handled during and following harvest. Studies are ongoing to identify affordable and effective product handling systems for Minnesota growers. During the conduct of the project, these included studies on produce cooling, cleaning, grading, packing, storage, and distribution. Since completion of the project, studies have focused on cooling, storage, and shelf-life extension.

The effectiveness of any project is measured by the results obtained. The major developments that have been realized since the $\mathrm{ABC}$ Project started are summarized below: 
A) Increased hectarage. Asparagus hectarage has increased by $\approx 40 \%$ statewide to $>1600$ ha and continues to increase slowly. Broccoli and cauliflower hectarage has been slower to develop. In 1983 , at the conclusion of the project, there was a combined area of $\approx 100$ ha, up from $<20$ ha in 1978 . Since 1983 , cauliflower hectarage has changed very little, but the area devoted to broccoli is increasing slowly. These records represent only those with which we are familiar; others probably exist. A major problem is that, like most states, Minnesota does not obtain hectarage statistics for most vegetable crops (except processing vegetables) as it does for other commodity crops. The principal growers responsible for the increase in production of these crops were participants in production conferences, grower tours, and other project activities.

B) More knowledgeable growers. Growers who participated in the $\mathrm{ABC}$ project have demonstrated that they now have a better understanding of the markets available to them and how to grow these crops. The understanding of product handling systems is progressing but seems more difficult for growers to comprehend and adopt.

C) Increased buyer awareness. Wholesale fresh produce buyers in Minnesota are now more aware of the production potential and product quality of asparagus, broccoli, and cauliflower grown in Minnesota when handled properly. Many retail dealers and wholesale buyers who participated in the project are more conscious of their product losses from improper product handling.

D) Increased government and university awareness. Public agencies were participants and observers of project activities and are now aware of the market potential of these and other vegetable crops and the impact they could have on the economy of the state. Disciplines outside of horticulture (project collaborators) at the University of Minnesota are now more aware of the technical needs and opportunities in vegetable crops production and marketing.

A project of this nature requires considerable effort from a team of individuals. For the $\mathrm{ABC}$ project, two other individuals made substantial commitments and contributions to the work-R.J. Dufault (currently Clemson Univ., Coastal Experiment Station) and J.R. Sutherland, Specrotech International, Inc., Minneapolis. Others also participated, including many growers.

\section{FOLLOWUP PROGRAM DEVELOPMENT AT THE UNIVERSITY OF MINNESOTA}

Termination of the ABC Project did not negate the need for work on alternative crops, especially in the horticultural area. This transition time coincided with the Midwest farm crisis, and there was considerable interest in new crop research and development programs. The results of the $\mathrm{ABC}$ project and this need led to the formation of The Center for Alternative Plant and Animal Products.

The Center is an interdepartmental organization within the Colleges of Agriculture and Natural Resources, the Minnesota Extension Service, and the Agricultural Experiment Station at the Univ. of Minnesota. There is representation on the steering committee from almost all disciplines of importance to agriculture, forestry, and related industries. Membership on the administrative board is from across disciplines and there is also a 15-member external advisory board representing most of the types of agribusiness in Minnesota. The center has been in development 4 years and continues to evolve. Major hurdles have included achieving committed involvement from faculty across disciplines and acquiring support.

The Center was created as an integrated, market-driven vehicle for: a) generating, receiving, and evaluating new product ideas; b) facilitating alternative enterprise and product research and development efforts; and c) disseminating information to the public on alternative plant and animal products. It arose out of faculty discussions exploring ways to achieve cooperation between disciplines on existing problems. These initial discussions were in horticulture but expanded rapidly to other plant and animal disciplines. The results of these discussions led to development of the Center, which deals with alternative crops across disciplines and alternative animal enterprises. Animal enterprises were included because animal agriculture is intimately involved in many new crop projects and, in addressing new animal enteprises, crop disciplines were involved.

\section{Center functions}

A principal intention of the steering committee was to have the Center act as a multidisciplinary clearinghouse for evaluating ideas. The Center seeks ideas from many sources: other faculty, industry groups, individuals with ideas, etc. The critical mission of the Center is the evaluation of ideas. Many different disciplines representing biology, economics, and the marketplace must participate to provide reasonable feasibility analysis of an idea. Early in Center development, it was decided that resources would not be invested in ideas that did not have potential commercial feasibility. There are many wonderful ideas, but very few have real commercial possibilities with the capability to attract research and development funding.

A second major function is support and coordination of research and development for projects that have commercial feasibility. The most obvious Center contributions to this process are overall coordination and assembling teams capable of and interested in participating in developing research projects. After a project is designed, the Center coordinates the search for funding and administers the project once funding is obtained. Through this process, the Center removes the administrative obstacles to getting work done and makes the work of the researchers more efficient and productive.

The Center has sponsored numerous in-depth symposia on subjects identified as having potential for diversification of agriculture and forestry. These symposia have many benefits: a) They are effective means of creating awareness that an opportunity exists in a new crop, product, or enterprise. b) They are a vehicle for assembling expertise from a wide geographic area that can, in the early stages of project development, provide input in all the important disciplines dealing with the opportunity. New grower organizations have also been initiated. c) Their proceedings are valuable reference documents because they deal with every aspect of the potential enterprise, including production, processing, marketing, economics, and distribution. d) They may lead 1) to other symposia, more focused and more in-depth, 2) directly to research projects, or 3) in some cases, to termination of interest in pursuing an idea.

Dissemination of research and development project results is another necessary function of the Center. Project results must be shared with funding sources and those with commercial interest. This dissemination can range from project reports to elaborate conferences and symposia designed to share information and/or to help generate commercial interest in the idea.

After the establishment of an organization such as the Center, it is necessary to be prepared to handle diverse inquiries. Nothing will kill an organization more quickly than promising something that cannot be delivered. Consequently, the Center has not yet made such a wholesale, comprehensive commitment to information delivery, but efforts are being made to handle the growing number of inquiries.

Simply serving as a contact point at the university is a more significant contribution than anyone had initially thought. Many people call the university and other public agencies looking for help and are routed to many sources of information before they actually find assistance. A typical caller may make six or more calls before reaching the appropriate source of help. The Center and other similar organizations within the university system can be effective contact points so that a caller can be helped directly or routed to help with only one additional call.

The paragraphs above have described active functions of the Center, but there are some other important Center activities that are more indirect: a) Developing cooperation among the university, industry, and public agencies. No single agency or organization has all the expertise needed in new enterprise development. Ways must be found to help individuals from these diverse parts of our society to work together enthusiastically toward a common goal. b) Providing a work environment that fosters real interdisciplinary work. For people to work together across disciplines, they must first want to, and the Center has tried to identify project participants who have existing interest in a particular enterprise or product. In addition to interest, they also bring existing resources and facilities to the project. Removing logistical and administrative headaches associated 
with doing project work establishes an environment in which people can enjoy working together. c) Providing responsiveness to agricultural problems. The public sector, and academic institutions in particular, are frequently accused of not being responsive to the real-world needs of the industrial sector. In many cases, institutions do not respond because they are not organized to respond. Faculty members within universities and employees of public agencies have defined areas of activity and responsibility. It can be very frustrating when requests for help are received outside of those areas because the organization may not provide a means for the inquiry to be passed on to the right person. The Center has been able to direct inquiries to an immediate source of help, evaluate ideas, and provide various forms of positive feedback.

\section{Linkages}

The Center is striving to develop effective linkages and relationships that are institutional, geographic, individual, industrial, and public. The success of most projects is determined by the strength of the relationships between participants.

Geography is often a serious boundary. It is easy to imagine that a location imposes uniqueness. In the work with alternative agricultural enterprises, there are so few people involved that it is hard to generate a comprehensive program without input from a wide geographic area.

None of the Center activities will have much chance of success without effective linkages with industry partners. Technology may never be adopted if industry is not involved in evaluation of ideas, planning of projects, and implementation of the results. In many cases, it is necessary to have an effective system for assignment of proprietary rights to technology or products, and provide assistance in adoption.

The public is more than just an interested bystander. In most cases, it is public money that will provide the salaries of the individuals involved in development work. Legislators frequently get questions from their constituents concerning where their dollars go. Consumers are interested in the kinds of products that they will be buying in the future, and the media always are interested. Interaction with the media (print, television, and radio) can have positive or negative effects. If managed properly, such interactions can be helpful in generating enthusiasm for programs.

\section{Funding}

In the development of the Center, almost a year was spent dealing with such issues as philosophy and process. It was necessary to be certain of the objectives of the Center and how those goals were going to be achieved. The initial funding came from the Minnesota Governor's Rural Development Council through a $\$ 10,000$ grant that allowed the Center to begin limited activities. Since then, through limited funding reallocation within the university, programs have continued to develop. Numerous proposals have been and continue to be submitted to various sources both for support and operation of the Center staff as well as for specific projects.

Recurring financial support for work on alternative enterprises is hard to find. Enthusiasm rises and falls with the prices of major commodities, and it will probably continue to be this way for the foreseeable future. It is encouraging, however, that there seems to be a growing interest in new crop work in the academic community, and there are funds available for specific, defined projects from various public and private sources.

Experiences in Minnesota indicate that there are many things that must happen for new or alternative enterprise efforts to succeed, but some factors are critical. There must be champions of the effort, commitment of time by participants, industry interest, priority given to these efforts by the academic administration, and money for routine operations as well as specific projects.

\section{Literature Cited}

Adler, P.R., R.J. Dufault, and L. Waters, Jr. 1984. Influence of nitrogen, phosphorus, and potassium on asparagus transplant quality. HortScience 19(4):565-566.

Adler, P.R., R.J. Dufault, and L. Waters, Jr. 1985. Ancymidol rates and application timing influence asparagus transplant growth. HortScience 20(2):196-198.

Dufault, R.J. and L. Waters, Jr. 1984. Propagation methods influence asparagus transplant quality and seedling growth. HortScience 19(6):866868.

Dufault, R.J. and L. Waters, Jr. 1985a. Interaction of nitrogen fertility and plant populations on transplanted broccoli and cauliflower yields. HortScience 20(1):127-128.

Dufault, R.J. and L. Waters, Jr. 1985b. Container size influences broccoli and cauliflower transplant growth but not yield. HortScience 20(4):682684.

Dufault, R.J., M.C. Burke, L. Waters, Jr., and W. Cranshaw. 1983. Growing asparagus in Minnesota. Minnesota Ext. Serv., Ext. Folder 666.

Waters, L., Jr., K. Reihle, R.J. Dufault, F.L. Pfleger, and W. Cranshaw. 1983. Growing broccoli and cauliflower in Minnesota. Minnesota Ext. Serv., Ext. Folder 667.

Waters, L., Jr. and M. Sherman. 1986. A vegetable tour/course. HortScience 21(6):1446-1447. 